\title{
THE METHODS OF EARLY WARNING AGAINST THE POSSIBILITY OF BANKRUPTCY - VERIFICATION OF THE MODELS
}

\author{
Wioletta Skibińska, PhD Ing., wskibinska@eranet.pl \\ Technical University of Czestochowa, Department of Management
}

\begin{abstract}
The article contains an evaluation of the quality and universal character of three models of prognosticating insolvency, constructed on the basis of discrimination analysis and artificial neural networks. The evaluation of the created models was conducted on the basis of four companies operating in different lines of business, which declared bankruptcy in the years 20022003. The objective of the verification was to find out, how many years in advance it was possible to predict insolvency with the help of the models in question, and whether the line of business in which a given company operated might influence the efficiency of the said models.
\end{abstract}

\section{Introduction}

In the market economy the functioning of every company is unavoidably connected with the necessity of assessing and verifying its financial situation. The early identification of the financial crisis is important not only for the company as such, but also for the businesses that cooperate with it, as it allows for the minimalisation of the costs connected with its possible insolvency.

Insolvency is a natural phenomenon, indirectly connected with the functioning of a company under the conditions of the market economy. On the one hand it is a positive factor, as it allows both the elimination from the market the inefficient companies and a more productive allocation of the resources of the insolvent companies in prosperous ones. On the other hand, it may happen that the prosperous companies, which, in their activities, come into contact with insolvent ones that cooperate with them, may develop financial problems, which consequently lead to their own insolvency.

In order to limit the risk of the insolvency of a company, it is useful to carry out constant evaluation of its financial liquidity and the degree of probability that it may be lost.

The most traditional method of evaluating the financial condition of a company is the indicator analysis. The results of the research have proved that the combination of this method with more complicated methods gives much better results in detection of the worsening financial condition of a company. It allows to develop a single, synthetic measure, which simultaneously and coherently utilizes several pieces of information about the financial situation of a company. At the same time the greater predicting ability of the indicators is accounted for.

The most efficient devices for prognosing the insolvency, and the most common ones, are the models based on the multidimensional discrimination analysis and the artificial neural networks. The great interest taken in this statistical method is connected with the fact that it is capable of producing very accurate prognoses. Simultaneously with the works leading to the perfection of the said method, the quantity methods of prognosing the insolvency are undergoing assessment.

The development of the information technology, especially the systems connected with data processing allow for the implementation of very complicated mathematical methods. Among those, a very important role play the artificial neural networks, which belong to the group of methods of so-called artificial intelligence. Such networks are utilized not only in prognosing the insolvency of companies, but also in other areas of research.

In the developed market economies the methods of prognosing insolvency have been known for several decades and are the subject of both the theoretical considerations and the empirical research. 
In Poland the phenomenon of insolvency became known at the beginning of the 90s when the transformation in economy started. As the stability of the market economy in Poland was growing, the group of potential receivers of the prognoses concerning the threat of insolvency was also growing. Thus, the methods of early warning against the insolvency became the subject of research on a greater scale.

As proves the experience of the developed countries, it is a mistake to apply the models developed under the conditions of a given market economy to the companies operating under the conditions of another market economy. The period of application of a given model in a given country is also of crucial importance. ${ }^{1}$ Before the models of prognosticating insolvency are actually utilized by the managers of companies, it is vital that they be very carefully verified by their creators, in order to evaluate their quality and to what extent they can be treated as universal ones.

The following article is devoted to the verification of the three models of prognosticating insolvency developed on the basis of the discrimination analysis and artificial neural networks, such as the linear network and the MLP network with one hidden stratum. ${ }^{2}$ The objective of this verification consists in finding out how long before the insolvency actually takes place it can be predicted with the help of these models, and to what extent the line of industry within which a company operates can influence the quality of the prognosis.

\section{Evaluation of the models of prognosticating insolvency}

The most serious problem faced during the period of data completion in order to create the models was the poor quality of the financial reports presented in the court of law by the insolvent companies. In many cases the financial situation of a company could not be evaluated due to the lack of sufficient data. The rough analysis of the conclusions confirms the fact that especially the small and medium-sized companies do not respect the law as far as filing the bankruptcy petition is concerned. Nearly all the petitions were filed behind time, and practically in all cases the assets of the companies were insufficient to cover their debts. Thus, the created models based on this sample of companies confirmed the great usefulness of warning against the insolvency only a year before it actually happened. Because of this fact, it is necessary to verify the models in order to find out whether they may detect the danger of insolvency two or three years in advance.

Very seldom do the authors of publications concerning the models of prognosticating insolvency discuss the universal character of the models in connection with the line of trade. However, it is a very important issue, connected with the differences in the interpretation of the financial indicators in particular lines. The differences are due to the shaping of the fixed assets and current assets in different lines of business, and the shaping of the company's own capital and extraneous capital. Generally speaking, they are due to the peculiarity of the functioning and operating of a given company in a given sector of economy. Table 1 presents an example of diversification in the data provided by some indicators for chosen lines of business.

\footnotetext{
${ }^{1}$ All those aspects are connected, first of all, with macroeconomic disparities, the peculiarities of a given economy and accounting system, as well as with the changes of the legal regulations.

${ }^{2}$ The detailed description of these models and their analytical form is included in the article: Skibinska W., Prognozowanie upadłości przedsiębiorstw za pomocą analizy dyskryminacyjnej i sztucznych sieci neuronowych [w:] Chrzan P. (red.), Metody matematyczne, ekonometryczne i informatyczne w finansach i ubezpieczeniach, Cz. 1, Wyd. AE im. K. Adamieckiego w Katowicach, Katowice 2006, s. 209
} 
Table 1. Diversification of the chosen financial indicators depending on the line of business

\begin{tabular}{|c|c|c|c|c|}
\hline \multirow{2}{*}{ Indicators } & \multicolumn{4}{|c|}{ Line of business } \\
\hline & Industry & Building trade & & Trade \\
\hline Current liquidity & 1,2 & 1,8 & & $1,5-1,9$ \\
\hline Fast liquidity & 1,0 & 1,5 & & $1,0-1,2$ \\
\hline Cycle of collecting receivables & 60 & 60 & & 60 \\
\hline Cycle of liabilities in days & 100 & 100 & & 100 \\
\hline Cycle of reserves in days & 130 or $45-80$ & - & & $-150 ; 30-20$ \\
\hline $\begin{array}{l}\text { Share of the company capital in } \\
\text { overall liabilities }(\%)\end{array}$ & 20 & 57 & 15 & $44-47$ \\
\hline $\begin{array}{l}\text { Overall gross rate of profitability } \\
\text { of the capital }(\%)\end{array}$ & 36 & - & & 39 \\
\hline $\begin{array}{l}\text { Overall net profitability of sales } \\
(\%)\end{array}$ & $7-9$ & - & & $6-10$ \\
\hline Rentowność netto sprzedaży (\%) & $15-30$ & - & & $33-42$ \\
\hline $\begin{array}{l}\text { Covering of the fixed assets with } \\
\text { company capital }\end{array}$ & pow. 1,0 & 1,6 & & $1,8-2,8$ \\
\hline $\begin{array}{l}\text { Covering of the fixed assets with } \\
\text { constant capital }\end{array}$ & pow. 1,0 & 1,8 & & $2,2-2,5$ \\
\hline
\end{tabular}

Source: Based on Siemińska E., Metody pomiaru i oceny kondycji finansowej przedsiębiorstwa, TNOiK, Toruń 2002, p. 126

Analyzing the contents of Table 1 we notice that the differences in the data provided by financial indicators of particular lines of business are quite considerable. Thus, the lines of business within which operate the sample companies serving as a basis for constructing a model ought to be kept in mind. It also should be ascertained that the potential user of the model may apply it for evaluation of the financial condition of their company receiving the results which actually reflect reality. Therefore, the creators of the models of prognosticating insolvency ought to verify the universal character of their models, testing and evaluating their quality by applying them for companies operating in different lines of business.

The objective of the choice of sample companies to the construction of the three models of prognosticating insolvency consisted in introducing certain limitations. That is, mainly limited liability companies operating in the production line were taken into account, which contributed to the receiving of good quality results both from the statistical and empirical point of view. The accuracy of classification of these models in the analytical sample amounted to $97,3 \%$ in the case of the model based on the discrimination analysis, $92,31 \%$ in the case of the model based on the linear network, and $95,38 \%$ in the case of the model based on MLP. The quality of the test sample classification for all three models amounted to $90 \%$. The assessment of correctness in the case of the scientifically described models of prognosing the insolvency allows for the conclusion that all of them are characterized by the highly correct qualification of the companies, both in the verifying attempt and in the model-designing attempt. Because of the high correctness of classification, the best of the presented models is the one based on the discrimination analysis. This is the proof that the discrimination analysis is rightly the most popular method of prognosing insolvency. The convenience of using the discrimination method is further proved by the fact that it does not demand the use of a computer system in practice, in order to receive the information about the present financial condition of the accompany, i.e., whether the company is actually threatened by 
the insolvency or not. This is connected with the lower costs of using the model, which is an important factor in the case of the small and medium-sized businesses.

The efficiency of the models was verified on the basis of four joint-stock companies from different lines of business, excluded from the public operation by the decision of Polish Security Exchange Commission (KPWiG) from 29 March 2005. ${ }^{3}$ The results of the verification are presented in Table 2.

Table 2. Verifying the efficiency of the models of prognosticating insolvency

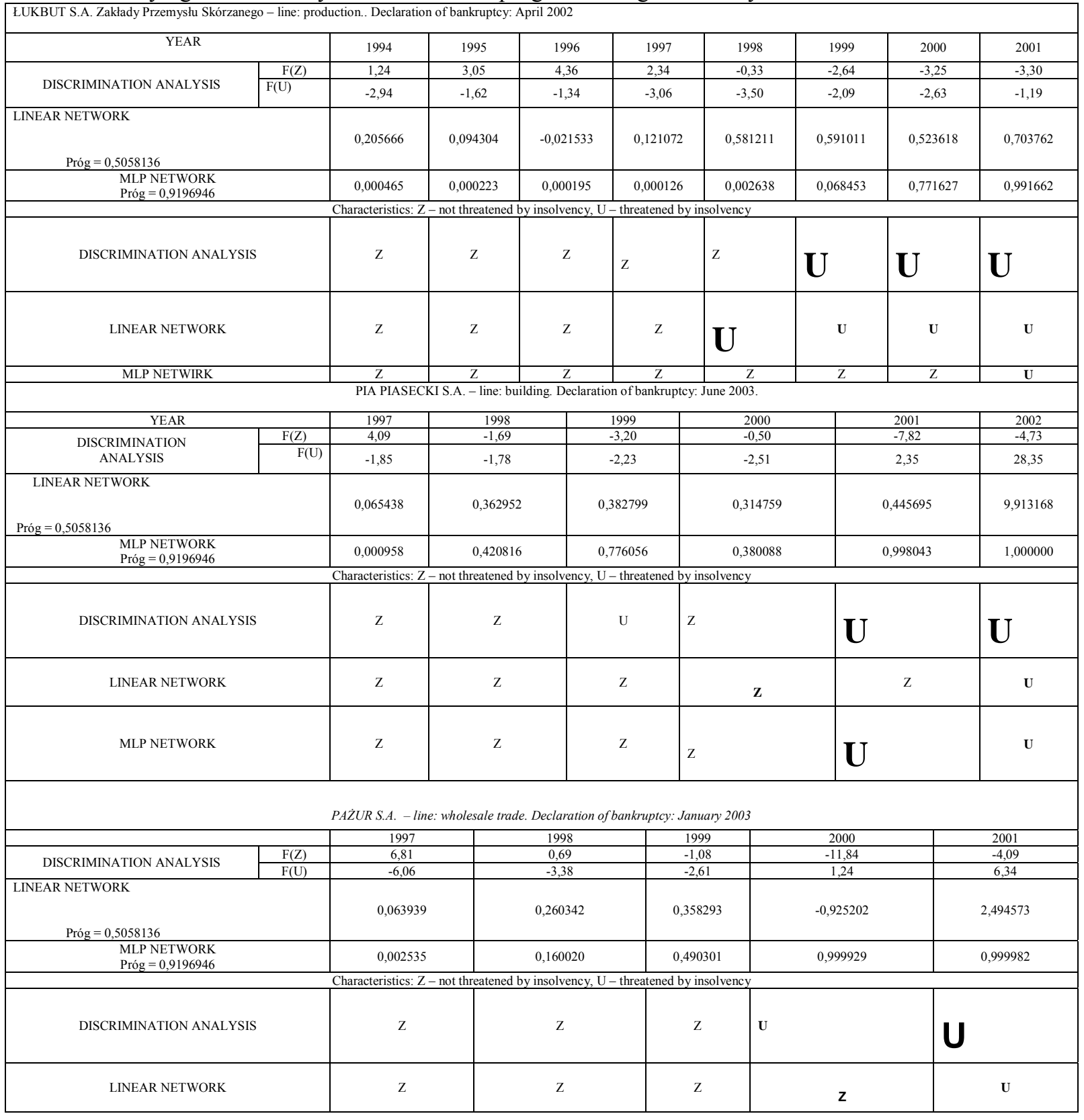

${ }^{3}$ An announcement of the CCCXI sitting of KPWiG on 29 March 2005. Information taken from the web page www.e$\underline{\text { msp.pl }}$

The financial reports of the analyzed companies have been excerpted from the information published by Notoria, i.e. a company which monitors and analyzes the financial operation of companies whose shares are traded on the stock exchange. 


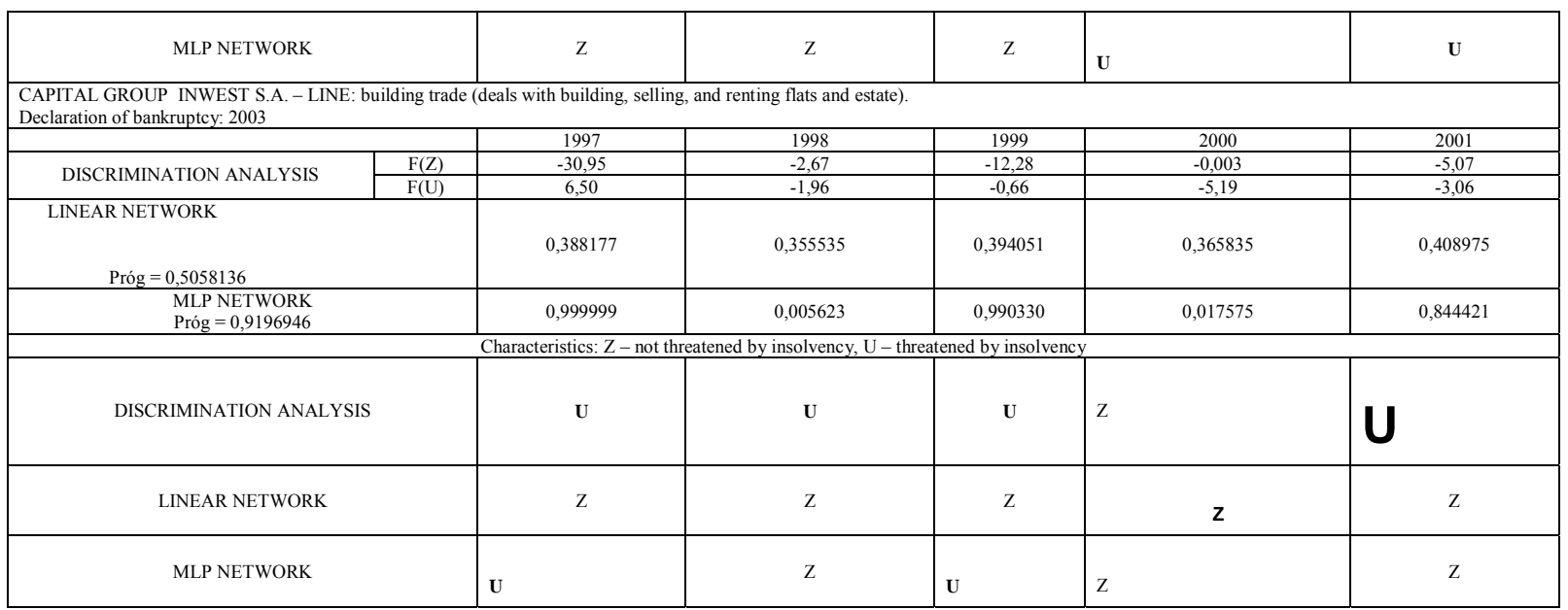

Source: Own elaboration.

The analysis of the contents of Table 2 leads to a conclusion that the highest level of efficiency in prognosticating insolvency of companies achieved the models applied in the company ŁUKBUT S.A., which declared bankruptcy in 2002. In the case of the model based on the discrimination analysis it was possible to predict the insolvency three years in advance, and in the case of the model based on the linear network, four years in advance. The fact of very early detection of the symptoms of oncoming bankruptcy in this company thanks to these models is conditioned by the fact that the company ŁUKBUT S.A. operates in the production line of business, and the created models were constructed on the sample of production companies, which prevailed in the sample by about $95 \%$.

Furthermore, the results of the analysis make it clear that the models show good prognosticating ability as far as the companies operating in other lines of business are concerned, i.e. in the case of the company PIA PIASECKI S.A. (building line) and PAŻUR S.A. (trade line), which both declared bankruptcy in 2003. The efficiency of the models in the case of these two companies is comparable. As indicate the contents of Table 2, with the help of the models based on discrimination analysis and MLP network, the bankruptcy of both companies could be predicted two years in advance, and with the help of the linear network model a year in advance. In the last of the analyzed companies, i.e. GKI S.A., the applied models showed no predicting potential as for confirming the approaching of oncoming bankruptcy, which was declared in 2003.

\section{Recapitulation}

As show the results of evaluating their efficiency, constructing models of prognosticating insolvency based on the homogeneous sample of companies make it possible to receive a high level of efficiency in predicting insolvency. In order to check the universal character and prognosticating quality of the constructed models, it is necessary to conduct further research based on a greater number of companies declaring bankruptcy, which will show precisely whether the constructed models may be applied in the case of any company, operating in any line of business. Such a research would provide a chance of putting into practice highly efficient models of prognosticating insolvency, resulting in the possibility of early detection of a financial crisis.

An interesting idea for the continuation of the studies concerning the methods of prognosing insolvency would consist in testing other methods than the discrimination analysis and artificial neural networks, in order to select the most prestigious method of early warning against the possibility of bankruptcy. 


\section{Bibliography:}

1. Siemińska E., Metody pomiaru i oceny kondycji finansowej przedsiębiorstwa, TNOiK, Torun 2002.

2. Skibińska W., Prognozowanie upadłości przedsiębiorstw za pomoca analizy dyskryminacyjnej $i$ sztucznych sieci neuronowych [w:] Chrzan P. (red.), Metody matematyczne, ekonometryczne i informatyczne $w$ finansach $i$ ubezpieczeniach, Cz. 1, Wyd. AE im. K. Adamieckiego w Katowicach, Katowice 2006, s. 20 
